\title{
Engineering Leadership as Principled Nonconformity
}

\section{Dr. Kathryn A. Neeley, University of Virginia}

Kathryn Neeley is Associate Professor of Science, Technology, and Society in the Engineering \& Society Department of the School of Engineering and Applied Science. She is a past chair of the Liberal Education/Engineering \& Society Division of ASEE and is particularly interested in the role of liberal education in developing engineering leaders. 


\title{
Engineering Leadership as Principled Nonconformity
}

\author{
Four years at MIT permanently solders some primary circuits of the mind, and perhaps for that \\ reason some modes of thinking seem permanently closed to me.
}

--Richard Meehan, Getting Sued and Other Tales of the Engineering Life, p. 18

\begin{abstract}
As a recent review article in the Leadership Quarterly (2014) ${ }^{1}$ reported, "Leadership development has emerged as an active field of theory building and research, providing a more scientific and evidence-based foundation to augment the long-standing practitioner interested in the topic" (p. 63). Like many of the papers submitted to the Engineering Leadership Development (LEAD) Division of ASEE, Day et $a l .{ }^{1}$ focus on areas where more experimental investigation and a stronger evidence base are needed. As a complement to that empirical, quantitative approach, this paper takes a philosophical approach to engineering leadership development.
\end{abstract}

For our purposes here, the term "philosophical" has two levels of meaning. The first level concerns the grounding principles and basic truths that establish the motivations and assumptions of engineering leadership These principles and truths help us explain, for example, why engineering leadership matters or why engineering leadership is different than other kinds of leadership. In this case, a grounding principle is that engineering education inculcates habits of mind that are constructive in most circumstances but can also constrain innovative thinking and leadership development. Based on this principle, leadership education for engineers means both developing an awareness of and a critical perspective on those habits of mind and doing something in addition to what engineering education usually does.

The second sense in which the approach advocated here is "philosophical" is that it draws on the concepts and analytical approaches of particular philosophers. For our purposes here, those philosophers include several who are well known (Aristotle, Martin Heidegger, Thomas Kuhn, and Mike Martin) and one who is not as well known but highly relevant to engineering leadership pedagogy (Carol Steiner).

Drawing on a classical antecedent of the trait approach to leadership, Aristotle's conception of virtue $^{3}$, I argue that authenticity, defined here as principled nonconformity, is an important but challenging virtue for engineering leaders, and that liberal education, broadly defined, is one of the best resources for developing that virtue.

Traits, Virtues, and Engineering Leadership Education

Defining leadership in terms of the traits that individual leaders possess "is perhaps the most venerable intellectual tradition in leadership research", (p. 855). Since at least the 1940s, leadership theorists have critiqued the trait perspective as an oversimplification that is much more useful for valorizing leaders after the fact than for producing them. As the authors of a review article on the leader trait paradigm expressed it, "Yes, leaders with the "right" traits are favored, but this observation does not address what the rest of us should do when we do not have the "right stuff" (p. 858). In other words, no clear pedagogical strategy emerges from such a 
view. It seems simply (and unhelpfully) descriptive. Aristotle's concept of virtue not only provides an analytical framework for describing why particular traits are beneficial but also provides a foundation for a pedagogical strategy and a flexible methodology for decision-making in a leadership context.

In a series of provocative articles published between 1995 and $2000^{3-5}$, Carol J. Steiner offered a philosophical approach for developing desirable traits in engineering leaders. Recognizing that the skills and attitudes required for leadership, innovation, and management, "are unlikely to be developed in conventional engineering education because they fall outside of the engineering paradigm"” (p. 1), she offers an approach to leadership education for engineers and scientists that is both pragmatic and philosophical.

Following Kuhn's ${ }^{6}$ notion of scientific education as indoctrination leading to membership in a discipline, Steiner defines competence "as being committed to the beliefs, practices, and values of one's discipline" and accepting "one's professional role and identity without challenge" ${ }^{4}$. 123). Following Heidigger, Steiner contrasts competence with authenticity and individuality and suggests that "Authentic persons are nonconformists who recognize their capacity to operate sometimes outside professional, cultural and social paradigms" 3 (p. 129). If one accepts these claims, it follows that engineering leadership requires what might be called "principled nonconformity" regarding the "beliefs, practices, and values" that engineering education aims to inculcate.

This paper develops the concept of principled nonconformity not in opposition to the paradigm that engineering education aims to impart, but rather as a learned skill in which engineers think critically about the dominant paradigms of their profession and develop the judgment required to discern when it is appropriate to depart from the dominant paradigm. The "principled" aspect presumes that engineers depart from the paradigm to serve the ideals of their profession, to optimize the good that engineering brings to society as a whole, to serve the long-term welfare of their employers, and to achieve fulfillment as individuals.

As Aristotle defines them, virtues are stable character traits that strike the mean between extremes; for example, courage (a virtue) is the mean between cowardice (a vice of deficiency) and foolhardiness (a vice of excess). The mean is not always the midpoint or average. Depending on the circumstances, the wise or courageous course of action might approach one of the extremes. Virtues benefit both the individual who possesses them and the society of which that individual is a part. Any given social group's definition of virtue depends on its vision of human flourishing (eudaimonia in Greek) or what is sometimes called "the good life." Virtue can only be cultivated and recognized within social groups.

This conception seems to have been developed in connection with leadership and ethics in business and education - and to engineering ethics, but has not, insofar as I have been able to determine, been widely applied to engineering leadership development.

Why Conformity Is Essential and Can Be Problematic in Engineering 
Accreditation is one of the most distinctive features of and influential processes in undergraduate engineering education. As the ABET website describes it, "accreditation is proof that a collegiate program has met certain standards necessary to produce [emphasis added] graduates who are ready to enter their professions. Students who graduate from accredited programs have access to enhanced opportunities in employment; licensure, registration and certification; graduate education and global mobility." 8 sympathetic reading of this description takes accreditation to be a process of quality control achieved through the cooperative activity of the various engineering professional societies, who collaborate to define the goals of engineering degree programs and to ensure that standards are maintained.

As Kuhn pointed out in The Structure of Scientific Revolutions, ${ }^{9}$ scientific groups would not be able to function "without some set of received beliefs" about fundamental concepts and questions. These beliefs, according to Kuhn, become "firmly embedded in the educational initiation that prepares and licenses the student for professional practice. Because that education is both rigorous and rigid, these answers come to exert a deep hold on the scientific mind" and "account both for the peculiar efficiency of the normal research activity and for the direction in which it proceeds at any given time"7 (p. 5). At one level, the key concepts of "standards" and "products" suggest a mental model of education as a mass production manufacturing process involving inert materials rather than living human beings. From another perspective, they make collaboration and productive cooperation possible on very large scales, possibly even including global.

But adherence to an established paradigm is not, as Steiner and others argue, conducive to innovation or high-level technical management. Drawing on definitions by DeNovellis ${ }^{9}$ that distinguish a technical person - "an individual with perceived competence or technical skill in a certain product or knowledge area, generally obtained from formal courses of specialized study" (p. 481)-from technical and non-technical managers, Steiner concludes that a willingness to operate outside of one's area of technical competence is essential for innovation, leadership, and technical management. As DeNovellis ${ }^{9}$ sees it, technical people, especially those who score higher on analytic and spatial skills, may not be able to "release from their prior roles related to technical competence. .. . and [develop] a management identity" (p. 482).

\section{Why Engineering Education Emphasizes Leadership and Maintains a Leadership Traits Focus}

Leadership by engineers - both individually and collectively_plays a prominent role in the "Aspirations for the Engineer of 2020" as presented in The Engineer of 2020: Visions of Engineering in the New Century. ${ }^{10}$ Although the stated purpose of the Engineer of 2020 Project is "to envision the future and to use that knowledge to attempt to predict [emphasis added] the roles that engineers will play in the future," 10 (p. xi) the substance of the report is at least as much concerned with aspirations as with predictions. Perhaps the most prominent of those aspirations is leadership. The "Attributes of Engineers in 2020"10 (the traits required to achieve the aspirations) include leadership as a broad category but list numerous additional traits that are frequently mentioned in literature on leadership, though with a distinctly engineering emphasis: strong analytical skills, practical ingenuity, creativity, communication, business and management skill, high ethical standards, professionalism, dynamism, agility, resilience, flexibility, and capacity for lifelong learning (pp. 54-56). The emphasis on these attributes reflects an 
assumption that engineers of the future will no longer be able to rely solely on a core body of expertise throughout their careers. Perhaps more importantly, it reflects a desire to see engineers and engineering exercise appropriate influence for the public good and to attract talented students to a profession that both pays well and provides personal fulfillment.

Engineering leadership programs as they are portrayed through their websites appear focus on curricula, requirements, and the benefits of possessing leadership skills. In general, they do not define in depth the problem their programs are designed to solve or the need their program meets. Where they do articulate the problem, it seems largely a problem of going beyond traditional engineering education. This perspective is illustrated in the statements of purpose summarized in the table below.

\begin{tabular}{|l|l|}
\hline $\begin{array}{l}\text { Leadon Engineering } \\
\text { Leadership Program (MIT) }\end{array}$ & $\begin{array}{l}\text { A purely technical engineering education is insufficient to } \\
\text { prepare engineering graduates for optimal effectiveness in } \\
\text { industry. Transforming this expertise into real products and } \\
\text { systems demands the development of additional capabilities, } \\
\text { character, and values. }\end{array}$ \\
\hline $\begin{array}{l}\text { Cornell Engineering } \\
\text { Leadership Program }\end{array}$ & $\begin{array}{l}\text { But technical skills alone are not enough. Turning ideas into } \\
\text { solutions, bringing innovations to life, influencing governments } \\
\text { and societies: these require engineers to step up as team } \\
\text { members and leaders. }\end{array}$ \\
\hline Rice Center for Engineering & $\begin{array}{l}\text { The difference between a "really smart" engineer and a } \\
\text { "leading engineer" is the ability to create and communicate a } \\
\text { shared vision, to build a high performing team, to develop and } \\
\text { execute shared plans, and to create innovations that } \\
\text { endure. These capabilities are not usually taught in traditional } \\
\text { engineering courses. }\end{array}$ \\
\hline
\end{tabular}

Authenticity as a Pedagogical Strategy for Engineering Leadership

Following Heidegger, Steiner contrasts competence with authenticity and individuality and suggests that "Authentic persons are nonconformists who recognize their capacity to operate sometimes outside professional, cultural and social paradigms", (p. 129). If one accepts these claims, it follows that engineering leadership requires principled nonconformity to the "beliefs, practices, and values" that engineering education is structured to inculcate.

There is little available detail on Steiner's career before she completed her dissertation in the Department of the History and Philosophy of Science at the University of Melbourne in 1995. That dissertation, which was titled Magic Moments: A Phenomenological Investigation of the Role of Authenticity in Innovation, began as a study of the communication in innovation at an unnamed firm she describes as "a commercial engineering consultancy that specializes in product and process innovation. ... [and has been] remarkably successful" as reflected by its own growth and profitability and "the commercial benefits it produces for its clients"3 (p. 2). 
Most of the employees of the consultancy were engineers of various types. Her project changed direction when she observed "the eccentric and idiosyncratic characters that populate[d] the consultancy" (p. 2). In particular, she noticed how much the employees talked about "the skills, qualities, and attitudes they look for (and have found) in innovators" (p.3 ). Although communication skills were often mentioned, they were far from being the only traits, which also included "wide vision, enthusiasm for diversity, innovation and change, a team orientation, a sense of ownership and responsibility to the team and client, appreciate of others contributions, and wiliness to learn new things" (p. 4). Instead of seeking a psychological or sociological explanation for how people within the consultancy developed these traits, she proposed a philosophical approach to developing in engineers "the characteristics of innovators and managers based on learned individuality/authenticity" (p. 4).

The philosopher Martin Heidegger provides the intellectual foundation for the approach. As one of the twentieth century's most articulate critics of technology, Heidegger would hardly seem likely to provide insight for engineering education. But there are two features that make him relevant to the world of engineering leadership. The first is a preference for what he calls "the public world," the messy, nonspecialized, complex, and interconnected world in which most people live. The second feature is a concern with the circumstances that allow human beings to fully realize their potential and individuality, a state he refers to as "authenticity." As Steiner summarizes Heidegger's authentic persons, they "are nonconformists who recognize their capacity to operate outside professional, cultural, and social paradigms. Authentic persons are characterized by ... a kind of decisiveness based on seeing situations as offering unique and special possibilities for action" (p. 5).

Inauthentic persons, on the other hand, "relate to the world through the mediation of a prescribed view rather than directly, so they miss out on the full complexity of the public world. ... They cannot reach their full potential because they deny themselves the complexity and full range of possibilities available to authentic individuals" (p. 5) Authenticity is not, however, a permanent characteristic of a person. It is most likely to be expressed in problematic situations "that prevent people operating on "automatic pilot" and "require people to decide whether they will be authentic or not" (p. 5).

\section{Liberal Education as a Resource for Developing Principled Nonconformity}

Defining authenticity, or principled nonconformity, as a goal leaves the question of how to develop it in engineering leaders. Like the ability to communicate, authenticity is a composite of many skills and traits. It is more a habit of mind than a body of knowledge. As Samuel Florman argued in The Civilized Engineer, ${ }^{19}$ "As liberal education improves our intellectual competence and expands our imagination, it also develops those qualities of intellectual curiosity and general understanding, those traits of grace and wit and poise, that characterize leaders" (p. xx). In the context of engineering leadership education, principled nonconformity means confronting what Florman called "the eternal problems of philosophy and art" (p. xxi). It entails grasping the "hardness" underlying the "softness" often associated with liberal education and harnessing the power of the personal in the context of large-scale sociotechnical systems. It means accessing modes of thought obscured by not erased by a professional education. 


\section{References}

1. Day, C.V., Fleenor, J.W., Atwater, L.E., Sturm, R.E., and McKee, R.A. (2014). Advances in leader and leadership development: A review of 25 years of research and theory. The Leadership Quarterly 25, pp. 6382.

2. Judge, T.A., Piccolo, R.F., and Kosalka, T. (2009). The Bright and Dark Sides of Leader Traits: A Review and Theoretical Extension of the Leader Trait Paradigm. The Leadership Quarterly 20, pp. 855-875.

3. Kraut, R. (2014). Aristotle's ethics. The Stanford Encyclopedia of Philosophy, Zalta, E.N., ed. URL = $<$ http:plato.stanford.edu/archives/sum2014/entries/Aristotle-ethics>

4. Steiner, C.J. (1998, February). Educating for innovation and management: the engineering educator's dilemma. IEEE Transactions on Education 41(1), pp. 1-7.

5. Steiner, C.J. (1999, August). Constructive Science and Technology Studies: On the Path to Being? Social Studies of Science, 29(4), pp. 583-616.

6. Steiner, C.J. (2000, April). Teaching scientists to be incompetent: Educating for industry work. Bulletin of Science, Technology \& Society 20 (2), pp. 123-132.

7. Steiner, C.J. and Reisinger, Y. (2005) Understanding Existential Authenticity. Annals of Tourism Research 33(2), pp. 299-318.

8. Landis, E.A., Hill, D., and Harvey, M.R. (2014). A synthesis of leadership theories and styles. Journal of Management Policy and Practice 15(2), pp. 97-100.

9. Kuhn, T. (1970). The Structure of Scientific Revolutions. Chicago, IL: University of Chicago Press.

10. ABET. www.abet.org "Why Accreditation Matters"

11. DeNovellis, R. (1992, November/December) Technical people, technical management, \& successful management-What are the challenges? Journal of Clinical Engineering 17(6), pp. 481-486.

12. Mogee, M.E. (1993, November). Educating innovation managers: Strategic issues for business and higher education. IEEE Transactions on Engineering Management 40(4), pp. 410-417.

13. National Academy of Engineering. (2004). The Engineer of 2020: Visions of Engineering in the New Century. Washington, D.C.: National Academies Press.

14. Northouse, P.G. (2004) Leadership: Theory and Practice. Thousand Oaks, CA: Sage.

15. Ollis, D.F., Neeley, K.A., and Luegenbiehl, H.C., Eds. (2004). Liberal Education in Twenty-First Century Engineering. New York: Peter Lang.

16. Orr, J.A. (1994). Summary of innovations in electrical engineering curricula. IEEE Transactions on Education 37(2), pp. 131-135.

17. Schaub, J.H. and Dickison, S.K., Eds. With Morris, M.D. (1982) Engineering and Humanities. New York: John Wiley.

18. Spencer, D.B. and Mehler, G. (2013, Summer). Opportunities in engineering education: Pathways to betterprepared students. The Bridge, pp. 24-30.

19. Florman, S. (1968). The civilized engineer. Engineering and the Liberal Arts. New York: McGraw Hill. 